\title{
Possibilities of Developing Sustainable World by Introducing Bioeconomy: Global Perspective
}

\author{
Szanse na zrównoważony rozwój świata poprzez \\ wprowadzenie biogospodarki: perspektywa globalna
}

\section{Oleh V. Skydan*, Maryna I. Yaremova**, Liudmyla V. Tarasovych ${ }^{\star \star \star}$, Vitalii Ye. Dankevych ${ }^{\star \star \star \star}$, Nataliia M. Kutsmus ${ }^{\star \star \star \star}$}

\author{
*Polissia National University, Department of Innovative Entrepreneurship and Investment \\ Activities, 10002, 7 Staryi Blvd., Zhytomyr, Ukraine \\ E-mail (Corresponding Author): skydan6375-6@murdoch.in, \\ ORCID: 0000-0003-4673-9620 \\ **Polissia National University, Department of Economics and Entrepreneurship, 10002, \\ 7 Staryi Blvd., Zhytomyr, Ukraine \\ ***Polissia National University, Department of Marketing, \\ 10002, 7 Staryi Blvd., Zhytomyr, Ukraine \\ ****Polissia National University, Department of International Economic Relations \\ and European Integration, 10002, 7 Staryi Blvd., Zhytomyr, Ukraine
}

\begin{abstract}
At the time of the study, the world economy is attempting to form a resource-efficient policy. The purpose of this study is to investigate the evolution of the development of strategies and tactics of bioeconomic policy in the international space. The study substantiated the specific features of the implementation of special state and regional programmes of the advanced countries of the world, which differ in socio-economic ideas and prospects for their implementation. The comparative review of strategies identified similarities and differences between them, which allowed to differentiate strategic documents for the implementation of bioeconomic policy in certain areas. The study provides graphic visualisation of distribution of the countries according to the established orientation. The authors of the study proved the convergent difference of bioeconomic policy within each of the above areas by development goals, key objectives, and means of achieving them in a certain spatial dimension.
\end{abstract}

Key words: strategic guidelines, biotechnological manifestation, bioresource direction, bioenergy

\section{Streszczenie}

W czasie przeprowadzania niniejszego badania gospodarka światowa próbuje opracować politykę efektywnego gospodarowania zasobami. Celem pracy jest zbadanie ewolucji rozwoju strategii i taktyk polityki bioekonomicznej w przestrzeni międzynarodowej. W badaniu przedstawiona jest specyfika realizacji specjalnych programów państwowych i regionalnych rozwiniętych krajów świata, różniących się ideami społeczno-gospodarczymi i perspektywami ich realizacji. Porównawczy przegląd strategii wskazał podobieństwa i różnice między nimi, co pozwoliło na wyodrębnienie dokumentów strategicznych do realizacji polityki biogospodarczej w określonych obszarach. Autorzy pracy wypracowali graficzną wizualizację rozmieszczenia krajów zgodnie z ustaloną orientacją. W wyniku badania udało się ujawnić zbieżną różnicę polityki biogospodarczej w każdym z powyższych obszarów ze względu na cele rozwojowe, cele kluczowe i sposoby ich osiągnięcia w określonym wymiarze przestrzennym. 


\section{Introduction}

The strengthening of global challenges caused by anthropogenic impact on the environment necessitates the search for innovative ways of production and consumption of tangible and intangible goods. In these conditions, a special role is played by the bioeconomic direction of sustainable development, the importance of which is emphasised by the rapid pace of its implementation in the international arena. European countries have made a considerable contribution to the development of bioeconomic policy, promoting their ideas for the development of innovative concepts. Strategic initiatives are covered in the specially developed state and regional programmes to support the bioeconomic principles of business, a targeted policy of promoting innovative ideas, which will create a resource-efficient and competitive market environment with minimal destructive effects on the natural environment. Therefore, the purpose of the study lies in a theoretical and applied justification of the directions of bioeconomic policy based on the comparative analysis of strategies and tactics of their implementation, taking into account the unique features and capabilities of the state.

The first mention of bioeconomics dates back to the second half of the 20th century in the works of the American economist of Romanian origin $\mathrm{N}$. Georgescu-Roegen (1971), who argued for the existence of thermodynamic law of entropy in economic processes, which necessitates minimising the consumption of scarce raw materials, because there is no other way to preserve existing reserves for future generations. Geneticists J. Enriquez-Cabot and R. Martinez have demonstrated a modern view of the bioeconomy development, emphasising the need to create a new economic sector related to the introduction of biotechnology in industrial production (Enriquez, 1998). K. McCornic and N. Kautto (2013) presented their reflections on the interpretation of such concepts as Knowledge-based bio-economy, Bio-based economy and Bioeconomy.

A relatively small number of domestic scientists express scientific interest in bioeconomics, but some of their studies deserve special attention. Among the constellation of researchers, a prominent place is occupied by the studies of M.P. Talavyria (2015), who argues about the combination of human and nature in the use of natural resources. V.V. Baidala (2017) emphasises the relationship between people arising in the process of production, exchange, distribution, and consumption of organic products, while V.M. Butenko (2016) identifies biotechnology in the production of organic products, which, in her opinion, will meet the needs of society without reducing the capabilities of future generations. A.M. Proshchalykina (2016) reduces the bioeconomy to a high-tech part of the economy, which will increase energy efficiency through the development of renewable energy and promote the greening of the industrial sect- or. One of the first attempts to conceptualise the interpretation of bioeconomics in Ukraine was made in 2008 in the study Trends in commercial biotechnology (Philp, 2018), published by scientists from the Institute of Chemistry and Chemical Technology of the Lviv Polytechnic National University.

The popularisation of bioeconomic research in Ukraine has been gaining momentum since the beginning of 2012 due to the approval of a strategic document on bioeconomic orientation in the European Union (Innovating for Sustainable Growth..., 2012) and the development of strategic prospects for bioeconomy in most European countries. A detailed review of the issue suggests that a substantial contribution to the development of European bioeconomic policy was made by the German Bioeconomy Council, which systematically studies the strategies of leading countries by components of goals, objectives, industry (Bioeconomy Policy. Part I..., 2015; Bioeconomy Policy. Part II..., 2015; Bioeconomy Policy. Part III..., 2018). At the same time, the development of a new bioeconomic policy has become a basic object of study in the research by L. Staffas, M. Gustavsson and K. McCormick (2013), who provide a detailed review of strategies within the Biobased economy and Bioeconomy. L. Kelleher, M. Henchion, and E. O’Neill (2019) reviewed the development of the bioeconomy in Ireland, R. Meyer (2017) analysed five major obstacles to bioeconomy development. Despite the considerable amount of scientific studies, the issues of argumentation of the directions of implementation of bioeconomic policy in the international space, which determines the choice of the study, remain understudied.

The theoretical and methodological framework of this study is formed by a systematic approach to studying the preconditions for the development of bioeconomic policy in the leading countries of the world. In the process of study, general scientific and special methods were used: abstract logical (establishing relationships and developing the author's interpretation), inductive and deductive methods of scientific cognition (systematisation of bioeconomy strategies and author's generalisation), descriptive analysis (to substantiate sectoral features of bioeconomy); heuristic technique (to generate options for solving the problem under study); graphic (to clearly display the results of the study). The advantage of the study lies in the author's approach to the study of sustainable world development, which involves the identification of biotechnological, bioenergetic, and bioresource approaches in the implementation of bioeconomic policy.

\section{Characteristics of the levels of the bioeconomy development on a global scale}

The promotion of bioeconomic objectives has been successfully carried out in parallel outside the European Union. The United States, Canada, Japan and 
Table 1. International perspective of bioeconomy strategies, compiled by the authors

\begin{tabular}{|c|c|c|c|}
\hline Country & Year & Programme title & Responsible institution \\
\hline Japan & $2010 / 2012$ & $\begin{array}{l}\text { National Plan for the Promotion of Biomass } \\
\text { Utilization (2010); } \\
\text { Biomass Industrialization Strategy (2012) }\end{array}$ & National Biomass Policy Council \\
\hline USA & $2012 / 2016$ & $\begin{array}{l}\text { The Bioeconomy Blueprint (2012); } \\
\text { Strategic Plan for a Thriving and Sustainable } \\
\text { Bioeconomy (2016) }\end{array}$ & $\begin{array}{l}\text { The White House Office; } \\
\text { The Department of Energy }\end{array}$ \\
\hline Malaysia & 2012 & $\begin{array}{lll}\begin{array}{l}\text { Bioeconomy } \\
(2012)\end{array} & \text { Transformation } & \text { Programme } \\
\end{array}$ & $\begin{array}{l}\text { Ministry of Science, Technology and } \\
\text { Innovation }\end{array}$ \\
\hline South Africa & 2013 & The Bio-economy Strategy & Department of Science and Technology \\
\hline $\begin{array}{l}\text { United } \\
\text { Kingdom }\end{array}$ & 2015 & $\begin{array}{l}\text { Building a high value bioeconomy: opportuni- } \\
\text { ties from waste (2015); } \\
\text { UK Synthetic Biology Strategy Plan Biodesign } \\
\text { for the Bioeconomy (2016) }\end{array}$ & $\begin{array}{l}\text { The House of Lords Science and Tech- } \\
\text { nology Select Committee; } \\
\text { The Synthetic Biology Leadership } \\
\text { Council }\end{array}$ \\
\hline Norway & 2016 & Familiar resources - undreamt possibilities & $\begin{array}{l}\text { Interministerial collaboration led by the } \\
\text { Ministry of Trade, Industry and Fisher- } \\
\text { ies }\end{array}$ \\
\hline Thailand & 2017 & Bioeconomy Roadmap & Pracharath Collaboration \\
\hline Canada & 2017 & A Forest Bioeconomy Framework for Canada & Canadian Council of Forest Ministers \\
\hline Argentina & 2017 & Bioeconomia Argentina & Ministry of Agro-Industry \\
\hline New Zealand & 2017 & Primary Sector Roadmap - Te Ao Turoa & Ministry for primary Industries \\
\hline
\end{tabular}

several other developed countries have recognised the bioeconomic direction as a priority development for the coming decades and have taken an active position on the formation of their national priorities in the bioeconomic direction (Table 1).

American strategic directions for the development of bioeconomic prospects are based on the guidelines of the OECD programme, which consider biotechnological research as the prerogative of the bioeconomy. The United States has recognised the bioeconomic direction as the most profitable and fast-growing sector of the economy for the next millennium, adopting its strategic programme in 2012, The National Bioeconomy Blueprint, which is divided into two parts. The first describes the background and development factors of the American bioeconomy, while the second covers strategic areas of the bioeconomy, namely regulatory barriers, human capital, bioeconomic partnerships, and covers research, tracing their path from laboratory to market. The strategy treats bioeconomy as one that is based on the use of biological science and innovation research for economic activity and social benefit (Bikse et al., 2019). The next updated Strategic Plan for a Thriving and Sustainable Bioeconomy programme was presented by the US Department of Energy and Renewable Energy in 2016 with a focus on improving the value chain, mobilising national biomass, researching consumer and market demand, and enhancing collaboration and cooperation (Asada et al., 2020).

In Canada, references to Bio-Based Economy (BBE) were first noted in the report Canadian Blueprint: Beyond Moose and Mountains, published by the National Industry Association, which promoted a competitive biotechnology ecosystem (The Canadian Blueprint..., 2009). The non-governmental organisation BioteCanada associated the bioeconomy with biotechnology, the implementation of which was considered potentially capable of improving the quality of life of the population and bringing the $\mathrm{Ca}$ nadian economy to a new competitive level. In 2011, one of Canada's provinces, British Columbia, initiated a bioeconomic council chaired by the Secretary of Labour, Tourism and Innovation to explore the region's potential for bioeconomy and accelerate revenue growth.

A significant breakthrough in Canada's bioeconomic policy has been the recognition of the Recommendation to Build Alberta's Bioeconomy (2013) as one of the most important policy documents, as it reflects a wide range of bioeconomic perspectives, not limited to the development of biotechnology. Emphasis is placed on the availability of natural potential, namely forest resources that can be actively used in the future. The deployment of bioeconomic policy at the national level begins with the approval of the strategy A Forest Bioeconomy Framework for Canada (2017), which emphasises the circular, competitive, and innovative manifestation of sustainable production. Bioeconomic policy is at different stages of development in the world. Apart from the approved specialised integrated programmes, which cover biotechnological research and bioenergy in a complementary relationship with the bioeconomy, some countries outline a single direction. Innovative studies of nano- and biotechnologies in various fields are the hallmark of many countries on the way to bioeconomic development (Table 2).

Despite the fact that, mainly, advanced countries are active consumers of biotech products, over the past decade, countries such as Kenya, Uganda, Paraguay, Uruguay, Namibia, Sri Lanka and others have significantly intensified their activities in this direction. Some countries recognise biotechnological research as key to the development of modern society. For ex- 
Table 2. Biotechnological manifestation of bioeconomic policy, compiled by the authors

\begin{tabular}{|c|c|c|c|}
\hline Country & Year & Programme title & Responsible institution \\
\hline South Korea & $2006 / 2012$ & $\begin{array}{l}\text { 2th Framework Plan for Promotion of Biotech- } \\
\text { nology (2006); } \\
\text { Strategy for Promotion of Industrial Biotech- } \\
\text { nology (2012) }\end{array}$ & Government \\
\hline Kenya & $2006 / 2011$ & $\begin{array}{l}\text { A National Biotechnology Development Policy } \\
\text { (2006); } \\
\text { National Bioprospecting Strategy (2011) }\end{array}$ & $\begin{array}{l}\text { Kenyan Cabinet; } \\
\text { Kenya national Council for Science and } \\
\text { Technology }\end{array}$ \\
\hline India & $2007 / 2014$ & $\begin{array}{l}\text { Biotechnology Development and Innovation } \\
\text { Strategy (2007); } \\
\text { Biotechnology Strategy II (2014) }\end{array}$ & Ministry foe Science and Technology \\
\hline Uganda & $2008 / 2014$ & $\begin{array}{l}\text { Renewable Energy Policy (2007); } \\
\text { National Biotechnology and Biosafety Policy } \\
\text { (2008); } \\
\text { Biomass Energy Strategy (2014) }\end{array}$ & $\begin{array}{l}\text { Ministry of Finance, Planning and Eco- } \\
\text { nomic Development; } \\
\text { Ministry of Energy and Mineral Develop- } \\
\text { ment }\end{array}$ \\
\hline Columbia & 2009 & $\begin{array}{l}\text { National Science, Technology and Innovation } \\
\text { Policy }\end{array}$ & $\begin{array}{l}\text { National Council for Economic and So- } \\
\text { cial Policy }\end{array}$ \\
\hline Tanzania & 2010 & National Biotechnology Policy & $\begin{array}{l}\text { Ministry of Communication, Science and } \\
\text { Technology }\end{array}$ \\
\hline Sri Lanka & 2010 & National Biotechnology Policy & $\begin{array}{l}\text { National Science Foundation Committee } \\
\text { on Biotechnology }\end{array}$ \\
\hline Paraguay & 2011 & $\begin{array}{l}\text { The Strategy on Agricultural and Forest Bio- } \\
\text { technology }\end{array}$ & $\begin{array}{l}\text { The Ministry of Agriculture and Live- } \\
\text { stock }\end{array}$ \\
\hline Uruguay & 2011 & The sector Plan on Biotechnology & Interministerial Committee \\
\hline Russia & 2012 & $\begin{array}{l}\text { Comprehensive programme for the Develop- } \\
\text { ment of Biotechnology }\end{array}$ & Ministry for Economic Development \\
\hline China & $2012 / 2016$ & $\begin{array}{l}\text { 12th FYP on Bioindustry Development (2012); } \\
\text { 13th FYP on Bioindustry Development (2016) }\end{array}$ & $\begin{array}{l}\text { The State Council (Science, Technology } \\
\text { and Education) }\end{array}$ \\
\hline Australia & $2013 / 2016$ & $\begin{array}{l}\text { National Collaborative Research Infrastructure } \\
\text { Strategy (2013); } \\
\text { Queensland Biofutures 10-Years-Roadmap and } \\
\text { Action Plan (2016) }\end{array}$ & $\begin{array}{l}\text { Department of Industry, Innovation, Cli- } \\
\text { mate Change, S\&R, Tertiary Education; } \\
\text { Queensland Department of State Devel- } \\
\text { opment }\end{array}$ \\
\hline Namibia & 2015 & $\begin{array}{l}\text { National Programme on Research, Science, } \\
\text { Technology and Innovation }\end{array}$ & $\begin{array}{l}\text { National Commission on Research, Sci- } \\
\text { ence and Technology }\end{array}$ \\
\hline Brazil & 2016 & $\begin{array}{l}\text { National Strategy for Science, Technology and } \\
\text { Innovation }\end{array}$ & $\begin{array}{l}\text { Ministry of Science, Technology and In- } \\
\text { novation }\end{array}$ \\
\hline
\end{tabular}

Table 3. Bioenergy legislation in the context of bioeconomic development, compiled by the authors

\begin{tabular}{|l|l|l|l|}
\hline \multicolumn{1}{|c|}{ Country } & Year & \multicolumn{1}{|c|}{ Programme title } & \multicolumn{1}{c|}{ Responsible institution } \\
\hline Senegal & 2006 & National Biofuel Strategy & $\begin{array}{l}\text { The Ministry of Agriculture } \\
\text { Corporation }\end{array}$ \\
\hline Nigeria & 2007 & Biofuel Policy and Incentives & $\begin{array}{l}\text { The Ministry of Energy and Water } \\
\text { Resources }\end{array}$ \\
\hline Mali & 2009 & $\begin{array}{l}\text { National Strategy for the Development of } \\
\text { Biofuels }\end{array}$ & Ministry of Energy \\
\hline Mozambique & 2009 & National Biofuel Police and Strategy & Inter-ministerial Commission on Biofuels \\
\hline Mexico & 2009 & The Bioenergy Strategy & $\begin{array}{l}\text { National Energy Policy (2014); } \\
\text { Grand Strategy of Agricultural Development } \\
\text { 2015-2045 (2015) }\end{array}$ \\
\hline Indonesia & $2014 /$ \\
\hline
\end{tabular}

ample, in Australia, the bioeconomic strategy as a separate official document is absent, but the policy of bioeconomic orientation is viewed through the lens of the implementation of biotechnological developments. The Australian Government is considering strategic perspectives for the implementation of biotechnology in virtually all industries, especially agriculture, forestry, and fisheries.

The Commonwealth Scientific and Industrial Research Organisation, which is responsible for research and works with leading institutions around the world, has demonstrated considerable interest in bioeconomy. The Commonwealth of Scientific and Industrial Research Organisation (CSIRO) has established a bioeconomic website that highlights Australia's prospects for bioeconomy and lists key national research related to bioeconomic development, including biosafety, climate adaptation, sustainable agriculture, water use, etc. Bioeconomic policy of some countries is limited only by bioenergy legislation (Table 3). 


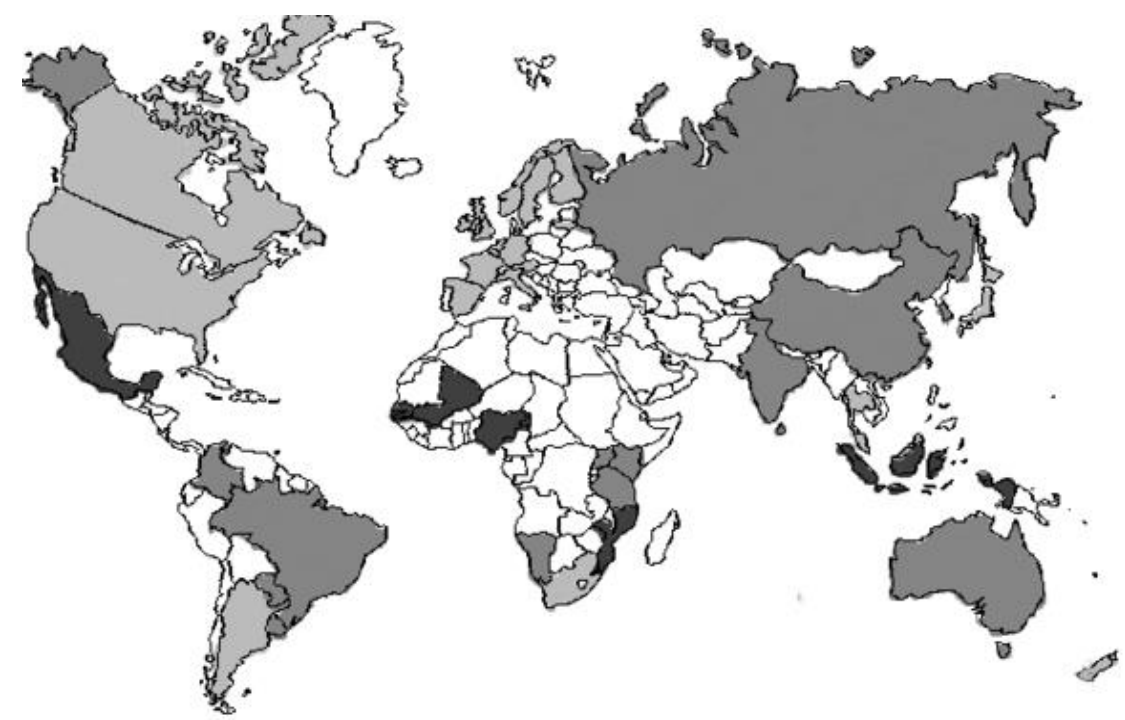

Figure 1. Differentiation of countries according to strategic bioeconomic development priorities, compiled by the authors Notes: $\square$ - bioenergetic direction; $\square$ - biotechnological direction; $\square$ - bioresource direction

Table 4. Features of bioeconomic policy implementation in key areas, compiled by the authors

\begin{tabular}{|l|l|l|l|}
\hline \multicolumn{1}{|c|}{ Direction } & \multicolumn{1}{|c|}{ Bioresource } & \multicolumn{1}{c|}{ Biotechnological } & \multicolumn{1}{c|}{ Bioenergetic } \\
\hline Socioeconomic idea & $\begin{array}{l}\text { Sustainable } \\
\text { development }\end{array}$ & Economic growth & Energy independence \\
\hline Development goals & $\begin{array}{l}\text { Biologisation of } \\
\text { production }\end{array}$ & $\begin{array}{l}\text { Commercialisation of scientific research } \\
\text { and biotechnological products }\end{array}$ & $\begin{array}{l}\text { Minimisation of dependence } \\
\text { on fossil fuels }\end{array}$ \\
\hline Tasks & $\begin{array}{l}\text { Consumption of safe } \\
\text { bioproduction }\end{array}$ & $\begin{array}{l}\text { Development of science and biotechnol- } \\
\text { ogies }\end{array}$ & Promotion of biofuels \\
\hline $\begin{array}{l}\text { Means of } \\
\text { achievement }\end{array}$ & $\begin{array}{l}\text { Natural resource } \\
\text { potential }\end{array}$ & Intellectual potential & Biomass potential \\
\hline $\begin{array}{l}\text { Implementation } \\
\text { approach }\end{array}$ & Synergetic & Interdisciplinary & Multidisciplinary \\
\hline Spatial dimension & $\begin{array}{l}\text { National and regional } \\
\text { level }\end{array}$ & Global and national level & $\begin{array}{l}\text { National level, } \\
\text { country territories }\end{array}$ \\
\hline
\end{tabular}

The main priority strategic goals in the development of bioeconomic policy of these countries are the production of fuel from renewable biological resources and the achievement of energy independence. Thus, considering the strategic priorities of the above legislative documents, it is proposed to identify the following key areas of bioeconomic policy development, namely:

- biotechnological, which provides, above all, economic benefits from the implementation of biotechnological research;

- bioenergy direction, given the isolation of bioenergy as a branch of the bioeconomy of individual states that prefer to meet energy needs without harming the environment;

- bioresource, which aims at the active use of biotic raw materials in the manufacture of food and non-food products.

The bioeconomic priorities of individual countries are visualised in Figure 1.

The map indicates the dark grey countries that are developing bioeconomic policy through the lens of biotechnological research. Black reflects the bioenergy advantage of states, while light grey highlights those who choose a bioresource direction for the de- velopment of bioeconomic policy, actively implementing strategic programmes that simultaneously cover the production of bioproducts, including biofuels and the implementation of biotechnological developments. The implementation of the bioeconomic policy of the European Union is dominated by the bioresource direction, which has been developing rapidly for several years in a row, meeting the key goals of sustainability. In the process of comparative review of strategies, clarification of similarities and differences between them, the study identified a set of socio-economic ideas, priorities and means to achieve them, as well as provided a spatial basis for the implementation of bioeconomic policy within the above directions (Table 4).

The socio-economic idea is to choose the priority areas of bioeconomic policy. Therefore, within the bioeconomic direction, the key goals of sustainable development prevail, which can be achieved through the biologisation of production to obtain safe and quality products. The biotechnology orientation is dominated by the possibility of commercialisation of scientific biotechnological developments for economic growth. The desire to obtain maximum energy independence through the transformation of biomass 
is implemented through the bioenergy direction. In conclusion, the development of an inclusive bioeconomy is possible only with all the components in their complementary interrelation during the implementation of the bioeconomic policy.

\section{Features of the European bioeconomy develop- ment}

The strategic bioeconomic document The Bioeconomy to 2030: Designing a Policy Agenda (2009) was first presented within the framework of the Organisation for Economic Co-operation and Development (OECD) project as part of the International Futures Programme, which proposed to consider the bioeconomy in the narrow meaning with an emphasis on biotechnological knowledge and its implementation in sustainable and competitive production to obtain additional economic results. The statutory imperative of this document was biotechnology, in particular, state aid for their development, cooperation with the private sector in this area, the establishment of intellectual property rights to encourage investment in biotechnology, the development of fundamental organisational principles for public dialogue on biotechnology.

The innovative approach to understanding the economy has aroused the interest of the international community, which has contributed to the active spread of the bioeconomic direction and the development of unique national strategies. Legislative documents in the above context have been initiated in almost 50 countries, most of which were within the European Union. Strategic perspectives differ in the components of goals, objectives, applications in industries; have their unique features and specifics depending on the capabilities of each state, its industry affiliation and the availability of natural resources. However, all strategies are closely linked to their social focus and emphasise the need to replace fossil fuels in industry and the energy sector with renewable biotic resources, reduce recycling materials and preserve the environment. The vision of the $\mathrm{Eu}-$ ropean Commission for the Development of the Bioeconomy is set forth in the strategy Innovating for Sustainable Growth: A Bioeconomy for Europe (2012). The strategic guidelines cover the following main aspects: increased investment in research and development; creation of favourable (political and economic) conditions for stakeholders; development of marketing communications.

The key focus of the European bioeconomy is on environmental growth, which can be achieved by improving the management mechanism of renewable biological resources and the development of an innovative, resource-efficient, and competitive society that would ensure the protection of the natural environment. The initial development of the European bioeconomy took place during the meeting in Lisbon (Portugal) in March 2000, which recognised the
Knowledge-based Economy (KBE) as the most competitive economy capable of achieving economic growth by meeting the social and environmental needs of society. Two key conferences became the theoretical basis for the further development of the bioeconomic paradigm. At the first international conference New perspectives on the Knowledgebased Bio-economy, J. Potochnik (2005) made a report Transforming life sciences knowledge into new, sustainable, eco-efficient and competitive products, where he presented the concept of Know-ledgebased Bio-economy. For the second time, the bioeconomic concept, which is based on biotechnological research, was recommended in 2007 at the international conference En Route to the KnowledgeBased BioEconomy in Cologne (Germany), which outlined the prospects for bioeconomics for the next 20 years.

The above events have contributed to the realisation that the bioeconomic concept has a unique potential for European countries which, however, had remained little known. The Belgian report at the conference The Knowledge-based Bio-economy towards 2020 in 2010 called for a shift in biotechnological emphasis to address key sustainability issues (Maes, Van Passel, 2019). An updated interpretation of the European bioeconomy was highlighted in the White Paper The European Bioeconomy in 2030, published by a community of several European platforms (Global Animal Health, Plants for the Future, Food for Life, Sustainable Chemistry, Sustainable Farm Animal Breeding and Reproduction, Forest Based Sector, Biofuels, Agricultural Engineering, Aquaculture and Innovation) within the Bio-Economy Technology Platforms project (BECOTEPS). According to the claims, bioeconomics belongs to sustainable production, which allows to transform biomass into a number of foods, health, industrial goods, and energy (The European Bioeconomy in 2030, 2011). The intensification of the bioeconomic direction in the European Union is especially connected with the development of a public-private partnership Biobased Industries (BBI), which is represented by European companies, small and mediumsized enterprises, voluntary associations conducting joint research. At that time, funding for research and technological development increased to 3.85 billion euros under the Eighth Framework Programme Horizon 2020 entitled Food security, Sustainable Agriculture and Forestry, Marine, Maritime and Inland Water Research and the Bioeconomy (20142020), which promotes bioeconomic policies in the EU (Schütte, 2018). As a result, annual turnover from the bioeconomy has increased by $25 \%$ over the last decade (Ramcilovic-Suominen, Pülzl, 2018). The renewed Horizon Europe 2020 programme (2021-2027) offers 10 billion euros for food and natural resources, including the bioeconomy.

In general, financing the development of the bioeconomy covers three key aspects, including invest- 
Table 5. Bioeconomic development programmes of the European Union, compiled by the authors

\begin{tabular}{|c|c|c|c|}
\hline Country & Year & Title & Responsible institution \\
\hline EU & $2012 / 2018$ & $\begin{array}{l}\text { Innovating for Sustainable Growth: Bioecon- } \\
\text { omy for Europe (2012); } \\
\text { A sustainable Bioeconomy for Europe: strength- } \\
\text { ening the connection between economy, society } \\
\text { and the Environment (2018) }\end{array}$ & European Commission \\
\hline Germany & $2010 / 2014$ & $\begin{array}{l}\text { National Research Strategy BioEconomy } 2030 \\
\text { (2010); } \\
\text { National Policy Strategy on Bioeconomy (2014) }\end{array}$ & $\begin{array}{l}\text { Federal Ministry for Education and } \\
\text { Research; } \\
\text { Interministerial collaboration }\end{array}$ \\
\hline Netherlands & 2012 & $\begin{array}{l}\text { Framework Memorandum on the Bio-based } \\
\text { Economy }\end{array}$ & Ministry of Economic Affairs \\
\hline Sweden & 2012 & $\begin{array}{l}\text { Swedish Research and Innovation Strategy for a } \\
\text { Biobased Economy }\end{array}$ & $\begin{array}{l}\text { Swedish Research Council; } \\
\text { Swedish Government Agency for In- } \\
\text { novation Systems; } \\
\text { Swedish Energy Agency }\end{array}$ \\
\hline Austria & 2013 & $\begin{array}{l}\text { Policy Paper on Bioeconomy (2013); } \\
\text { Research, Technology and Innovation Strategy } \\
\text { (2014); } \\
\text { Bioeconomy A Strategy for Austria (2019) }\end{array}$ & $\begin{array}{l}\text { Ministry of Transport, Innovation and } \\
\text { Technology; } \\
\text { Ministry of Education, Science and } \\
\text { Research; } \\
\text { Ministry of Sustainability and Tour- } \\
\text { ism }\end{array}$ \\
\hline Finland & 2014 & $\begin{array}{l}\text { The Finnish Bioeconomy Strategy Sustainable } \\
\text { Growth from Bioeconomy (2014) }\end{array}$ & $\begin{array}{l}\text { Ministry of Employment and the } \\
\text { Economy }\end{array}$ \\
\hline Belgium & 2014 & Bioeconomy in Flanders & Interdepartmental Working Group \\
\hline Spain & $2016 / 2018$ & $\begin{array}{l}\text { The Spanish Bioeconomy Strategy - } 2030 \text { Hori- } \\
\text { zon }\end{array}$ & $\begin{array}{l}\text { The Ministry of Agriculture, Food } \\
\text { and the Environment; } \\
\text { The Ministry of the Economy and } \\
\text { Competitiveness }\end{array}$ \\
\hline Italy & 2017 & $\begin{array}{l}\text { Bioeconomy in Italy: A unique opportunity to } \\
\text { reconnect economy, society and environment }\end{array}$ & $\begin{array}{l}\text { The Italian Presidency of the Council } \\
\text { of Ministers }\end{array}$ \\
\hline Latvia & 2017 & Latvian Bioeconomy Strategy 2030 & Ministry of Agriculture \\
\hline France & 2017 & A Bioeconomy Strategy for France & Interministerial collaboration \\
\hline Ireland & 2018 & National Policy Statement on the Bioeconomy & Government of Ireland \\
\hline
\end{tabular}

ment in research and development (R\&D); implementation of innovative developments in business processes and popularisation of bioeconomic principles of management among the public. Further European initiatives are aimed at implementing the above aspects, which provoked the establishment of a venture fund for the development of a circular bioeconomy with the support of the European Commission and the European Investment Bank with funding of 250 billion euros, which will allow to achieve the goals of the European Green Course. The bioeconomy strategy in an improved interpretation, $A$ sustainable Bioeconomy for Europe: strengthening the connection between economy, society and the environment (2018). The updated version provides a comprehensive action plan aimed at large-scale expansion of the bioeconomic aspect and its implementation, mainly in all industries and agriculture in order to achieve the goals of sustainable development and implementation of the Paris Climate Agreement, which replaced the Kyoto Protocol and entered into force in 2016 (Table 5).
The bioeconomic policy of the European Union is focused on expanding investment in research and development; increasing competitiveness and strengthening market positions of organic products; intensifying political interest and promoting the bioeconomic foundations of management in general. Leading position in the development of the bioeconomy among European countries is occupied by Germany, which was one of the first in the international arena to publish its national strategy entitled National Research Strategy BioEconomy 2030 (2011), which provides a specific course of bioeconomic orientation in agriculture, forestry, and fisheries, developed for the next six years. After lengthy negotiations and discussions, a revised National Policy Strategy on Bioeconomy (2014) was adopted under the auspices of the Federal Ministry of Food and Agriculture, which sets out strategic goals, systemic approaches and practical recommendations for conducting business on biological renewable raw materials and proposals on the implementation of technical and economic changes in bioproduction technology. 
A considerable role in shaping Germany's bioeconomic prospects is played by the independent advisory body of the Federal Government, the German Bioeconomy Council, established in 2009 with the participation of experts from scientific institutions to provide advice on economic and political principles of operation and practical application of the bioeconomy broadly, that is, in trade, agriculture and forestry, horticulture, fishing, woodworking, paper, textile, chemical, and pharmaceutical industries (Viaggi, 2018). In the same year, the Bioeconomy Science Center was established in North Rhine-Westphalia, the first institution to deal with bioeconomy problematics. Therewith, research on this subject is conducted in 60 German universities and 37 specialised higher education institutions related to the bioeconomy have been established. In addition, $61 \mathrm{com}-$ munities and 17 departmental institutions are engaged in developments in the bioeconomic sector (Urmetzer et al., 2018).

Among European countries, the Netherlands also takes an active position in the context of the bioeconomy, focusing mainly on agriculture and the food industry. As for Finland, its advantages are the availability of considerable forest reserves, which identified the key motives of the bioeconomy programme and contributed to the innovative development of the bioindustry. Swedish Research and Innovation Strategy for a Biobased Economy (2012) identifies knowledge gaps and examines key research needed for bioeconomy development, namely more economical use of fossil resources and their replacement by biotic raw materials, changes in the structure of consumption of quality products, cooperation between scientific institutions and industry. In general, the Swedish bioeconomy reflects national perspectives in a global context.

After several years of preparation, at the end of 2015, Spain intensified its national bioeconomy strategy, which was focused mainly on food production. The priority sectors were agriculture, forestry and fisheries, as well as the chemical and bioenergy sectors. Financial support for the implementation of the strategy was provided by the Spanish government and the European Union programme Horizon 2020.

\section{Conclusions}

Bioeconomic policy is widely implemented in most developed countries. The prerogative of its implementation for some is to maintain leading positions in the international arena and generate additional income from innovative products (biotechnology), while the dominant goals of other countries are to achieve sustainable development goals, including promoting food security, mitigating change climate, reducing the burden on ecosystems, etc. (bioresource direction). Other countries are limited to the transformation of the energy sector on a bioeconomic basis, which allows to achieve partial energy independ- ence (bioenergy direction). Strategic guidelines dep end on the availability of natural resource and intellectual potential, as well as the possibility of their implementation within the state.

\section{References}

1. A Forest Bioeconomy Framework For Canada, 2017, https://www.ccfm.org/pdf/10a\%20Document $\% 20-\% 20$ Forest $\% 20$ Bioeconomy $\% 20$ Framework\% 20for\%20Canada\%20-\%20E.pdf (12.10.2020).

2. A Sustainable Bioeconomy for Europe: Strengthening the Connection Between Economy, Society and the Environment, 2018, https://ec.europa.eu/research/bioeconomy/pdf/ec_bioeconomy_strategy_ 2018.pdf\#view=fit\&pagemode $=$ none $(21.10 .2020)$.

3. ASADA R., CARDELLINI G., MAIR-BAUERNFEIND C., WENGER J., HAAS V., HOLZER D., STERN T., 2020, Effective Bioeconomy? A MRIOBased Socioeconomic and Environmental Impact Assessment of Generic Sectoral Innovations, Technological Forecasting and Social Change, 153: 119946.

4. BAIDALA V.V., 2017, Macroeconomic Factors of Bioeconomy Development, National University of Bioresources and Natural History of Ukraine, Kyiv.

5. BIKSE V., LUSENA-EZERA I., VOLKOVA T., RIVZA B., 2019, European Bioeconomy Policy and New Opportunities for Bio-Based Business Development, International Multidisciplinary Scientific GeoConference Surveying Geology and Mining Ecology Management, SGEM, 19(5.3): 317-325.

6. Bioeconomy Policy, Part I Synopsis and Analysis of Strategies in the G7, 2015, https://knowledge4policy.ec.europa.eu/publication/bioeconomy-policy-sy nopsis-analysis-strategies-g7_en (16.10.2020).

7. Bioeconomy Policy, Part II, Synopsis of National Strategies Around the World, 2015, https://biooekon omierat.de/fileadmin/international/Bioeconomy-Pol icy_Part-II.pdf (26.10.2020).

8. Bioeconomy Policy, Part III, Update Report of National Strategies Around the World, 2018, https:// knowledge4policy.ec.europa.eu/publication/bioeco nomy-policy-part-iii-update-report-national-strategies-around-world_en (13.10.2020).

9. BUTENKO V.M., 2016, Bioeconomics as a Mechanism for Achieving Sustainable Development Goals, Bulletin of Agrarian Science of the Black Sea Coast, 1: 19-28.

10. ENRIQUEZ J., 1998, Genomics and the World's Economy, Science, 281: 925-926.

11. GEORGESCU-ROEGEN N., 1971, The Entropy Law and the Economic Process, Harvard University Press, Cambridge.

12. Innovating for Sustainable Growth: A Bioeconomy for Europe, 2012, https://ec.europa.eu/research/bioeconomy/pdf/official-strategy_en.pdf (18.10.2020).

13. KELLEHER L., HENCHION M., O'NEILL E., 2019, Policy Coherence and the Transition to a Bioeconomy: The Case of Ireland, Sustainability, 11: 7247.

14. MAES D., VAN PASSEL S., 2019, Effective Bioeconomy Policies for the Uptake of Innovative Technologies under Resource Constraints, Biomass and Bioenergy, 120: 91-106. 
15. MCCORNICK K., KAUTO N., 2013, The Bioeconomy in Europe: An Overview, Sustainability, 5: 2589-2608.

16. MEYER R., 2017, Bioeconomy Strategies: Contexts, Visions, Guiding Implementation Principles and Resulting Debates, Sustainability, 9(6): 1031.

17. National Policy Strategy on Bioeconomy, 2014, http://www.bioways.eu/download.php?f=62\&l=en $\& \mathrm{key}=\mathrm{c} 21 \mathrm{c} 2 \mathrm{ea} 7 \mathrm{e} 095424 \mathrm{f} 3545 \mathrm{c} 66 \mathrm{da} 7 \mathrm{~b} 98821$ (12.10.2020)

18. National Research Strategy Bioeconomy 2030, 2011, https://knowledge4policy.ec.europa.eu/publication/national-research-strategy-bioeconomy-2030 _en (11.10.2020).

19. PHILP J., 2018, The Bioeconomy, the Challenge of the Century for Policy Makers, New Biotechnology, 40: 11-19.

20. POTOCHNIK J., 2005, Transforming Life Sciences Knowledge into New, Sustainable, Eco-Efficient and Competitive Products, Conference on Knowledge-Based Bio-Economy, https://ec.europa. eu/commission/presscorner/detail/en/SPEECH_05_ 513 (12.10.2020).

21. PROSHCHALYKINA A.M., 2016, Preconditions of Bioeconomy's Formation and Development, http://www.m.nayka.com.ua/?op=1\&j=efektyvnaekonomika\&s=ua\&z=5314 (18.10.2020).

22. RAMCILOVIC-SUOMINEN S., PÜLZL H., 2018, Sustainable Development - A 'Selling Point' of the Emerging EU Bioeconomy Policy Framework? Journal of Cleaner Production, 172: 4170-4180.

23. Recommendation to Build Alberta's Bioeconomy, 2013, https://albertainnovates.ca/wp-content/upload s/2019/09/bioe_final_report_web_may2013.pdf (12.10.2020)
24. SCHÜTTE G., 2018, What Kind of Innovation Policy does the Bioeconomy Need?, New Biotechnology, 40: 82-86.

25. STAFFAS L., GUSTAVSSON M., MCCORMICK K., 2013, Strategies and Policies for the Bioeconomy and Bio-Based Economy: An Analysis of Official National Approaches, Sustainability, 5: 2751-2769.

26. Swedish Research and Innovation Strategy for a Bio-based Economy, 2012, https://www.formas.se/ download/18.462d60ec167c69393b91e60f/1549956 092919/Strategy_Biobased_Ekonomy_hela.pdf (24.10.2020).

27. TALAVYRIA M.P., 2015, Development of BioOriented Economy on a Scientific Basis, Scientific Bulletin of Uzhhorod University, 1(2): 225-229.

28. The Bioeconomy to 2030: Designing a Policy Agenda, 2009, https://www.oecd.org/futures/longtermtechnologicalsocietalchallenges/42837897.pdf (15.10.2020).

29. The Canadian Blueprint: Beyond Moose and Mountains, 2009, https://issuu.com/biotecanada_insights/ docs/beyondmm_english_final (24.10.2020).

30. The European Bioeconomy in 2030, 2011, http:// www.plantetp.org/system/files/publications/files/th he_european_bioeconomy_brochure_web_final.pdf (19.10.2020).

31. URMETZER S., SCHLAILE M.P., BOGNER K.B., MUELLER M., PYKA A., 2018, Exploring the Dedicated Knowledge Base of a Transformation Towards a Sustainable Bioeconomy, Sustainability (Switzerland), 10(6): 1694

32. VIAGGI D., 2018, Bioeconomy and the Common Agricultural Policy: Will a Strategy in Search of Policies Meet a Policy in Search of Strategies? Bio-Based and Applied Economics, 7(2): 179-190. 